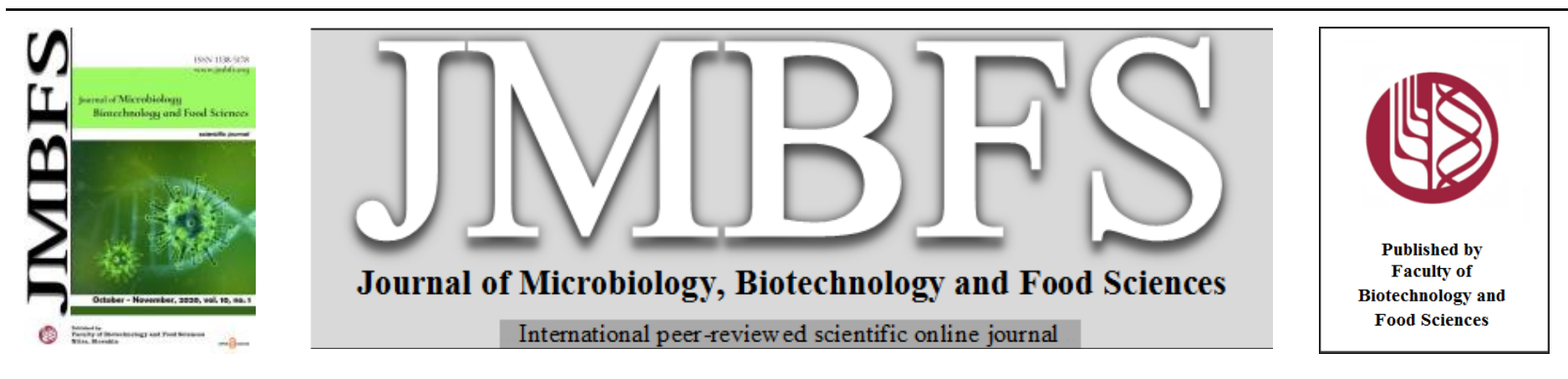

\title{
EVALUATION OF ANTI-CRYPTOCOCCAL ACTIVITY OF BACITRACIN
}

\author{
Neelabh and Karuna Singh*
}

Address(es):

Department of Zoology, MMV, Banaras Hindu University, Varanasi-221005.

*Corresponding author: karunasingh.bhu1@gmail.com

doi: 10.15414/jmbfs.2020.10.2.176-181

ARTICLE INFO

Received 14. 2. 2020

Revised 10. 6. 2020

Accepted 11. 6. 2020

Published 1. 10. 2020

Regular article

OPEN $\partial_{\text {ACCESS }}$

\begin{abstract}
Cryptococcosis is amongst potentially deadly diseases whose impact has aggrandized with the advent of AIDS and antifungal resistance. Antifungals used presently are short of broad spectrum activity and furthermore are involved in several side effects. Henceforth, the present manuscript focuses on the evaluation of antifungal activity of bacitracin against Cryptococcus neoformans var. grubii, the causative agent of the disease.

Minimum inhibitory concentration, flow cytometric analysis and confocal microscopy were used to determine the in-vitro fungal susceptibilities. Light microscopy was used to determine the changes in the micromorphology of the fungal organism. Swiss mice were used for testing the efficacy of bacitracin in-vivo.

Bacitracin showed cidal activity against $C$. $n$. grubii at $5.5 \mathrm{mg} / \mathrm{ml}$ which is on the higher side but on testing under in-vivo conditions it was observed that doses as high as $15 \mathrm{mg} / \mathrm{kg}$ bw/day did not show any adverse effect in the body. Better survival rate of the bacitracin treated mice, lowering of the fungal load and changes showing improvement in the tissue morphology depicts the mild anticryptococcal activity of bacitracin.

Although, bacitracin has proved to be a potent antifungal yet there are several limitations like low bioavailability and its peptide nature. However, these problems can be limited by developing suitable analogs of the compound.
\end{abstract}

Keywords: Cryptococcus neoformans; Bacitracin, in-vitro; in-vivo

\section{INTRODUCTION}

Since recent past an upswing in the field of drug development has been observed. However, the antifungal drug development scenario still requires a major boost. Two major classes of the antifungals, polyenes and azoles, have side effects. Even the most commonly used antifungal amphotericin B results in electrolyte imbalances and also nephrotoxicity (Clements et al. 1990, Enoch et al. 2006) Further, the development of resistance is also seen as a common problem in immunosuppressed hosts who received long term treatment (Saravolatz et al. 2003). Side effects and narrow spectrum activity of synthetic antifungals and cost effectiveness of plant based antifungals have lead to the search of other options including antifungal peptides.

The scientific fraternity along with the pharmaceutical giants are striving hard to develop new antifungals that could counter these dreadful diseases even though the situation is becoming graver by the day. This can be attributed to the lesser number of available targets against the fungi owing to their eukaryotic nature. Therefore, this argument intensifies the need to look for new antifungals which have a broad spectrum activity and lesser toxicity (Roemer and Krysan, 2014). The concept of compounds produced by bacteria that have antifungal activity is not new. Many reports on this idea have already been published (Weidman, 1927, Waksman, 1941). According to them, bacitracin is one of the compounds that effects bacteria and also has antifungal effect on some fungal pathogens. It is a group of cyclic peptides produced on the multi-enzyme complex as a component of the innate defence system of Bacillus licheniformis and Bacillus subtilis. It has unique property to interact with metals which affects its antibacterial activity. Significant stability at lower temperatures, acidic pH, solubility in water and certain organic solvents are other noticeable properties of bacitracin (Johnson et al. 1945).

Antibacterial activity of bacitracin is already known against gram positive cocci and bacilli, including Staphylococcus, Streptococcus, and Clostridium difficile as well as some Archaebacteria such as Methanobacterium, Methanococcus, and Halococcus (Johnson et al. 1945, Meleney and Johnson, 1949, Mescher et al. 1974) but less is known about its antifungal activity (Chitarra et al. 2013).

Bacitracin works by inhibiting the interaction of the components of the peptidoglycan i.e. (NAG and NAM) with bactroprenol pyrophosphate which normally carries them to the outer membrane for the building up of the cell wall in bacteria. However, in fungi, protein disulfide isomerase (PDI) can be a target of bacitracin (Dickerhof et al. 2011). Endoplasmic reticulum houses PDI protein that functions as a molecular chaperone and aids in the folding of the enzyme by catalyzing the formation, cleavage, and rearrangement of the disulfide bonds in unfolded or misfolded proteins (Wilkinson and Gilbert, 2004, Freedman et al. 2002, Serve et al. 2012, Wang et al. 2015).

This study aims to evaluate the antifungal potential of bacitracin against $C$. neoformans var. grubii (ATCC 6352).

\section{MATERIALS AND METHODS}

In this study C. n. grubii (ATCC 6352) was used as the test organism. Cryptococcus neoformans var. grubii (ATCC 6352) was kindly provided by Prof. S.M. Singh (Retd.), Department of Biological Sciences, Rani Durgavati Vishwavidyalaya, Jabalpur, India. All the isolates were sub-cultured on Sabouraud's Dextrose Agar (SDA) medium, incubated at $32^{\circ} \mathrm{C}$ for 48 hours (Perfect, 2006) and used for further experimentation.

\section{In-vitro susceptibility testing}

The susceptibility of $C$. $n$. grubii against bacitracin (HIMEDIA, CMS208) was tested by qualitative (Agar Disc diffusion and Broth macrodilution) as well as quantitative (Flow cytometry) assays. In each case amphotericin B (Trade name: Amphotret procured from Bharat Serums) was used as positive control.

\section{Minimum Inhibitory Concentration (MIC) by broth macrodilution method (CLSI M27- A3)}

The minimum inhibitory concentration $\left(\mathrm{MIC}_{90}\right)$ of bacitracin was determined by broth macro-dilution method. The stock solution of bacitracin in distilled water $(220 \mathrm{mg} / \mathrm{ml}$ ) was diluted with MOPS buffered RPMI to attain concentrations ranging from $22 \mathrm{mg} / \mathrm{ml}$ to $1.375 \mathrm{mg} / \mathrm{ml}$ and $200 \mu \mathrm{l}$ of each concentration was dispensed in separate tubes. Fungal inoculum $(1.8 \mathrm{ml})$ was then added in each tube. For amphotericin B, a concentration range of $1.95 \mu \mathrm{g} / \mathrm{ml}$ to $125 \mu \mathrm{g} / \mathrm{ml}$ was employed. The tubes were incubated without shaking at $32^{\circ} \mathrm{C}$ for 48 hours. Absorbance was taken using spectrophotometer (Thermo Scientific UV1). The experiment was performed in triplicate and standard error mean was calculated. 
Determination of fungicidal activity Confocal microscopy

Fungal inoculum was prepared in Yeast Extract-Peptone-Dextrose (YPD) broth having a concentration of $0.5 \mathrm{McFarland}$ and $900 \mathrm{ul}$ of the same was added to control and experimental tubes. Then $100 \mathrm{ul}$ of distilled water and bacitracin $(5.5$ $\mathrm{mg} / \mathrm{ml}$ ) was added to the control and experimental tube respectively. After incubation at $32^{\circ} \mathrm{C}$ for 48 hours, both the tubes were centrifuged (6000 rpm for 10 minutes). Subsequently, the pellet was re-suspended in $1: 1$ ratio (v/v) of DAPI ( $20 \mathrm{ul} / \mathrm{ml}$ of a $1 \mathrm{mg} / \mathrm{ml}$ stock in PBS) and PI (20 ul/ml of $1 \mathrm{mg} / \mathrm{ml}$ stock in PBS) simultaneously for 1 hour (Martinez et al. 2008). One drop of the above solution was now placed on the Poly-L-lysine coated slides, mounted with DABCO and observed in the confocal microscope (Zeiss).

\section{Determination of minimum fungicidal concentration (MFC) by Flow Cytometry}

For flow cytometric analysis, $220 \mathrm{mg} / \mathrm{ml}, 110 \mathrm{mg} / \mathrm{ml}, 55 \mathrm{mg} / \mathrm{ml}, 27.5 \mathrm{mg} / \mathrm{ml}$ and $13.75 \mathrm{mg} / \mathrm{ml}$ concentrations of bacitracin were added to the cell suspension prepared in YPD broth having $2 \times 10^{6}$ cells of $C$. $n$. grubii (ATCC 6352) diluting it in the ratio of $1: 9$. Tubes were incubated in shaker incubator at $32^{\circ} \mathrm{C}$ for 24 hours. Centrifugation $(6000 \mathrm{rpm}$ for 10 minutes) was done in order to pellet down the cells followed by re-suspension in propidium iodide solution $(25 \mu \mathrm{g} / \mathrm{ml}$ in phosphate-buffered saline) for a period of 30 minutes at $32^{\circ} \mathrm{C}$. For sample analysis, cell size (forward scatter of incident laser light) and propidium iodide (PI) fluorescence intensity data were collected for 10,000 cells with a BD FACS cell sorter (Green et al. 1994). Readings were recorded in triplicate. Minimum fungicidal concentration (MFC) was calculated by determining $R_{2} / R_{1}$ (Ratio of the dead cells to the living cells in a population of 10,000 cells).

\section{Micro-morphological study}

The micromorphology of the cryptococcal cells was examined through direct microscopy after treating them with $5.5 \mathrm{mg} / \mathrm{ml}$ concentration of bacitracin for 24 hours followed by staining with lactophenol cotton blue.

\section{In-vivo studies}

Animals

Swiss mice (C3HHC-Strain) weighing approximately $26 \mathrm{gm}$ were selected for experimental induction of cryptococcosis. The animals were fed ad libitum and photoperiod of a diurnal cycle was maintained. The experimental animals were divided into five groups (5 mice/group): immunocompetent control (ICC), immunosuppressed control (ISC), immunosuppressed diseased induced (ISD), immunosuppressed treated with bacitracin (IST) and immunosuppressed treated with amphotericin B (ISTA). Animals were maintained in accordance with the recommendations of Animal Ethical Committee of Banaras Hindu University.

\section{Inoculum preparation}

The test inoculum was prepared by transferring 2-3 loopful of the C.n. grubii (ATCC 6352) in $100 \mathrm{ml}$ normal saline containing $0.05 \mathrm{mg} \mathrm{m}^{-1}$ chloramphenicol. The fungal suspension was shaken for one hour then filtered through sterilized muslin cloth. The test inoculum was adjusted to $2 \times 10^{6} \mathrm{cfu} / \mathrm{ml}$ using haemocytometer.

\section{Treatment Plan}

Apart from the mice of the ICC group all the other mice were subjected to immunosuppression and disease induction (Singh et al. 2017). Following immunosuppression, all the experimental mice of disease induced and treated groups (ISD, IST and ISTA) were injected with $50 \mu \mathrm{l}$ of inoculum intravenously (IV) (Zaragoza et al. 2007) till two weeks on each alternate day. At $15^{\text {th }}$ day of experiment, mice of the IST group were treated with $15 \mathrm{mg} / \mathrm{kg}$ bw/day of bacitracin divided into 2 doses through intramuscular route. Additionally, the ISTA group mice were treated with $5 \mathrm{mg} / \mathrm{kg}$ of amphotericin B through the intravenous route. The animals were sacrificed after 5 weeks of inoculation. The mortality/survival was recorded for each group. Visceral organs of the mice were removed and cut into two halves. One half was proceeded for histopathology and the other half was used for biochemical studies and fungal load determination.

\section{Survivalship curve}

Kaplan-Meier plot was drawn by using Graph Pad Prism ver. 6.0 exhibiting the survival ship curve.

\section{Fungal load determination}

For fungal load determination tissue homogenates were prepared which were diluted with PBS in the ratio of 1:2.5 (CSF and Blood) and 1:2 (tissue homogenates) and were spread on SDA plates. Fungal load was calculated on the basis of colonies recovered/100 $\mu \mathrm{l}$ of tissue homogenate/CSF/blood.

\section{Histopathology}

The tissue samples fixed in $10 \%$ neutral buffered formalin were dehydrated with different grades of ethanol and embedded in paraffin wax $\left(60-62^{\circ} \mathrm{C}\right)$. The sections $(5 \mu \mathrm{m})$ were cut and stained with Haematoxylene-Eosin and Southgate's mucicarmine.

Determination of level of circulating leucocytes through Differential cell count (DLC):

For DLC, blood was obtained from each mouse belonging to each group and a thin smear was prepared. After drying, the blood smears were stained with Leishman's stain.

\section{Biochemical assays}

Protein content in the tissues was determined by Lowry's method (Lowry et al. 1951) following which Malondialdehyde (MDA) assay (Ohkawa et al. 1979) Catalase activity (Aebi 1974) and Superoxide dismutase assay (Das et al. 2000) were carried out.

\section{Statistical analyses}

Statistical analyses have been performed wherever necessary using GraphPad Prism version 6.0

\section{RESULTS}

\section{In-vitro susceptibility}

\section{Minimum inhibitory concentration}

The minimum inhibitory concentration of bacitracin against $C$. $n$. grubii (ATCC 6352) was found to be $5.5 \mathrm{mg} / \mathrm{ml}$. The minimum inhibitory concentration of amphotericin B was also calculated against the same fungus and was found to be $3.125 \mu \mathrm{g} / \mathrm{ml}$ (Table 1)

Table 1 Minimum inhibitory concentration of bacitracin and amphotericin B against C. n. grubii (ATCC 6352).

\begin{tabular}{lll}
\hline Fungal pathogen & Bacitracin* & Amp B* \\
\hline C.n.grubii (ATCC 6352) & $5.5 \mathrm{mg} / \mathrm{ml}( \pm 0.827)$ & $3.125 \mu \mathrm{g} / \mathrm{ml}( \pm 0.531)$ \\
\hline
\end{tabular}

*All readings are Mean \pm SEM

\section{Determination of fungicidal activity}

\section{Confocal microscopy}

All the nucleated cells were stained with DAPI (blue) whereas all the dead cells were stained with propidium iodide (red). Confocal microscopy depicts the anticryptococcal nature of bacitracin because a very high number of propidium iodide stained cells can be observed in the experimental panel (Figure 1e) as compared to the control panel (Figure 1b).

DAP
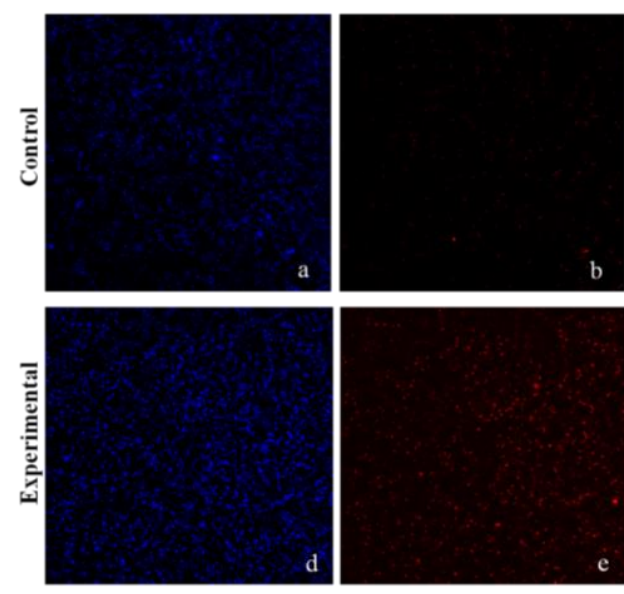

Figure 1 Confocal micrographs of cryptococcal cells: (a) all the nucleated cell stained with DAPI; (b) all the dead cells stained with PI (untreated); (c) merged 
image of a \& b; (d) all the nucleated cells stained with DAPI; (e) all the dead cells stained with PI (treated with bacitracin) and (f) merged image of d \& e.

Determination of minimum fungicidal concentration
As the concentration of bacitracin increased from $1.375 \mathrm{mg} / \mathrm{ml}$ to $11 \mathrm{mg} / \mathrm{ml}$ (Figure 2b, 2c, 2d and 2e), the number of cells in $\mathrm{R}_{2}$ (dead) region increased in comparison to the live cells $\left(\mathrm{R}_{1}\right)$ region. There is less than $20 \%$ difference in the $\%$ gated $\mathrm{R}_{2} / \mathrm{R}_{1}$ values of $11 \mathrm{mg} / \mathrm{ml}$ concentration and $5.5 \mathrm{mg} / \mathrm{ml}$, therefore 5.5 $\mathrm{mg} / \mathrm{ml}$ can be considered as the MFC of bacitracin against $C$. $n$. grubii (ATCC 6352) (Figure 2f).
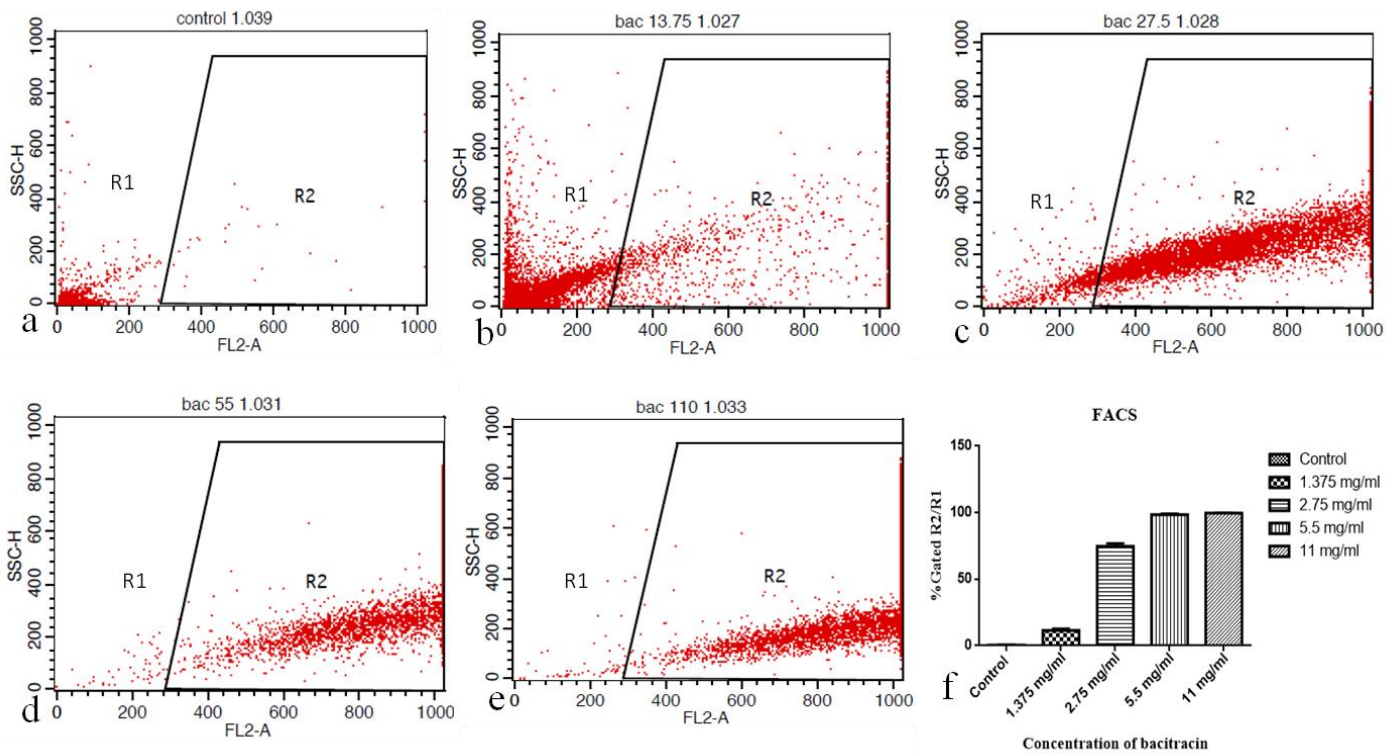

Figure 2 Effect of bacitracin at (b) concentration $1.375 \mathrm{mg} / \mathrm{ml}$; (c) $2.75 \mathrm{mg} / \mathrm{ml}$; (d) $5.5 \mathrm{mg} / \mathrm{ml}$; (e) $11 \mathrm{mg} / \mathrm{ml}$; (a) Control and (f) Ratio of $\%$ gated $\mathrm{R}_{2} / \mathrm{R}_{1}$

\section{Micro-morphological study}

Bacitracin induced minor changes in the cell morphology of $C$. n. grubii. The wrinkled cell wall of cryptococci suggests that yeast cells are in stress (Figure 3).

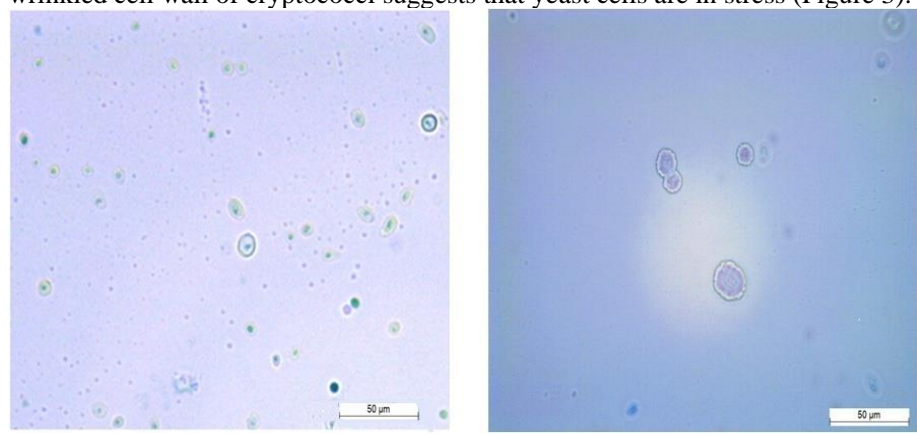

Figure 3 Effect of bacitracin on micromorphology of C. n.grubii (a) untreated $(\times$ $400)$ and (b) treated after 24 hours $(\times 400)$ (Lactophenol Cotton blue)

\section{In-vivo studies}

\section{Morphological and behavioral observations}

Morphologically, all experimental mice appeared normal. However, mice of disease induced group (ISD) showed ataxia and torticollis (clinical manifestations of cryptococcal meningitis).

\section{Survival curve}

Kaplan Meier survivalship curve depicts that the ISD group had a 20\% survival rate till the end of the experiment however this percentage was found to be increased $(40 \%)$ after the treatment with bacitracin in case of IST group. In ISTA group $60 \%$ survival rate was observed (Figure 4).

\section{Survival Curve}

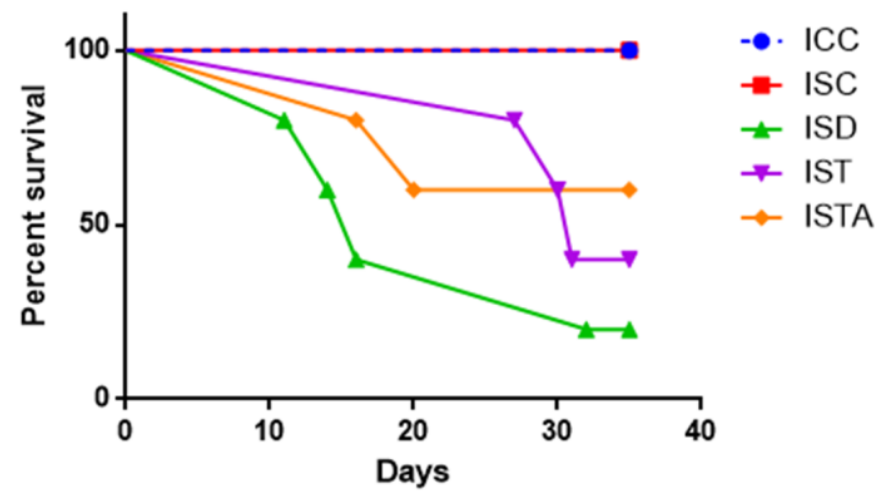

Figure 4 Kaplan-Meier plot for percentage survival.

\section{Fungal Load determination}

No cryptococcal colonies were seen in the normal control (ICC) and the immunesuppressed control (ISC) groups. The disease induced group (ISD), however, showed the highest number of colonies in all the organs along with CSF and blood (maximum in CSF and minimum in liver). Bacitracin treated group showed a reduction in the number of cryptococcal colonies validating the efficacy of the peptide (Table 2).

$\underline{\text { Table } 2 \text { Fungal load (no. of colonies recovered } / 100 \mu \mathrm{l})}$

\begin{tabular}{lll}
\hline Tissue homogenate (1:2 PBS) & CSF & Blood \\
& $(1: 2.5$ PBS $)$ & $(1: 2.5$ PBS $)$
\end{tabular}

\begin{tabular}{llllllllll}
\hline Groups & Liver & Lung & Kidney & Spleen & Heart & Brain & Stomach & & \\
\hline ICC & 0 & 0 & 0 & 0 & 0 & 0 & 0 & 0 & 0 \\
\hline ISC & 0 & 0 & 0 & 0 & 0 & 0 & 0 & 0 & 0 \\
\hline ISD* & $52 \pm 2$ & $97 \pm 3$ & $115 \pm 5$ & $161 \pm 6$ & 0 & $128 \pm 7$ & $195 \pm 8$ & $735 \pm 19$ & $187 \pm 6$ \\
\hline IST* & $11 \pm 1$ & $15 \pm 1$ & $56 \pm 2$ & 0 & 0 & $74 \pm 3$ & $150 \pm 6$ & $155 \pm 3$ & $70 \pm 2$ \\
\hline ISTA* & $15 \pm 1$ & $25 \pm 3$ & $25 \pm 2$ & 0 & 0 & $33 \pm 1$ & $35 \pm 1$ & $140 \pm 4$ & $45 \pm 2$ \\
\hline *Mean \pm SEM & & & & & & & & &
\end{tabular}




\section{Histopathology}

Liver

Liver of disease induced mice showed highly dilated sinusoidal spaces, the presence of erythrocytes, binucleated cells, pyknotic cells and hemorrhage (Figure 5b) whereas histopathological sections of liver of treated group showed binucleated cells and pyknotic cells along with signs of recovery like norma sinusoidal spaces and less number of hemorrhage spots (Figure 5c).

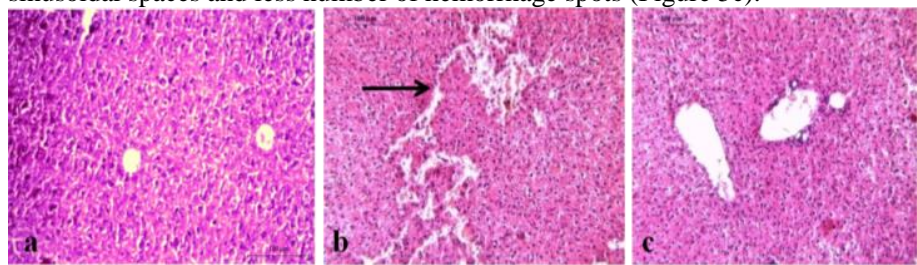

Figure 5 TS of liver: (a) Control, HE $(\times 100)$; (b) Arrow shows irregula sinusoidal spaces in disease induced mouse, HE $(\times 100)$ and $(c)$ Recovery with signs of pathogenesis in bacitracin treated mouse, $\mathrm{HE}(\times 100)$.

\section{Lungs}

Lungs of disease induced mice exhibited broken bronchiolar walls (Figure 6.6b) while the lungs of the treated group showed intact bronchiolar wall with some regions of hemorrhage (Figure $6 \mathrm{c}$ ).

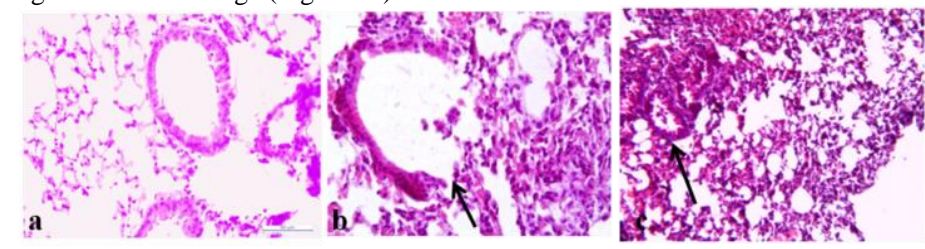

Figure 6 TS of lung: (a) Control, HE $(\times 400)$; (b) Bronchiole destruction (ISD group), $\mathrm{HE}(\times 400)$ and $(\mathrm{c})$ Hemorrhage, $\mathrm{HE}(\times 100)$.

Determination of the level of circulating leucocytes through Differential Leucocyte count (DLC)

Lowering in the number of neutrophils and increase in the number of lymphocytes was seen in the disease induced group (ISD) in comparison to the normal control group (ICC). However, on intramuscular treatment of bacitracin, the level of both neutrophils and lymphocytes became in consistence with the normal control group. However, DLC profile of amphotericin B treated animals showed neutropenia and lymphocytosis (Figure 7).

\section{Differential leucocyte count}

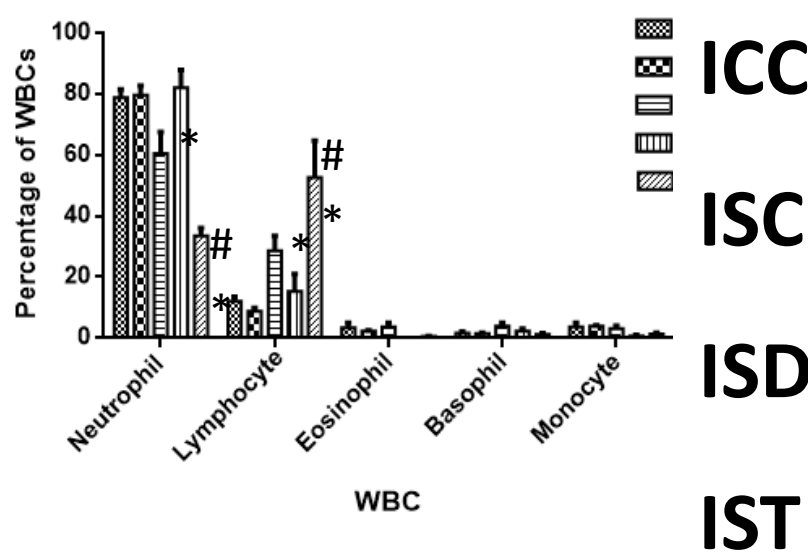

Figure 7 Differential leucocyte count of control as well as experimental mice (ICC -Immunocompetent control; ISC -Immunosuppressed control; ISDImmunosuppressed disease induced; IST- Immunosuppressed treated with bacitracin and ISTA- Immunosuppressed treated with amphotericin B. Values are Mean \pm SEM, $(\mathrm{n}=5) ; * \mathrm{P}<0.05$ and $\# * \mathrm{P}<0.0001$ (Statistically significant compared with normal control, ICC : using GraphPad style).

\section{Biochemical assays}

The SOD levels of both, liver and lungs were found to be reduced in the ISD group when compared to the control group. The SOD levels of the IST and ISTA groups were found to be higher than the ISD group for both liver and lungs (Figure 8a).

Likewise, level of catalase, in liver and lungs was found to be higher in ISD group and lower in mice of IST and ISTA groups in comparison to disease induced group (Figure 8b).

Similar to the catalase levels, an increase in the MDA levels was also observed in the ISD group which was found to be reduced in the bacitracin treated group (IST) and amphotericin B treated group (ISTA) (Figure 8c).

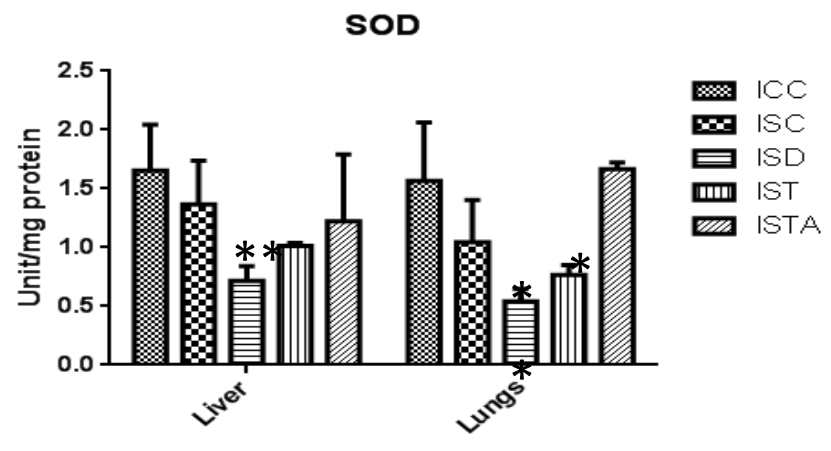

a
Organs

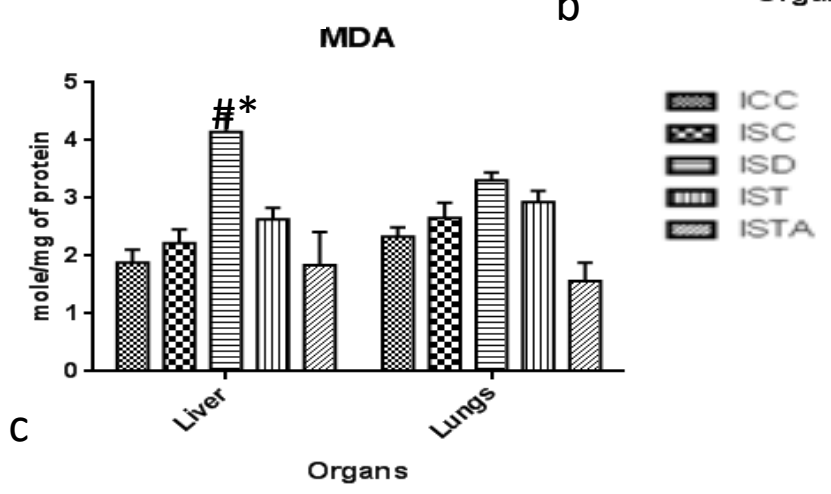

\section{Catalase}

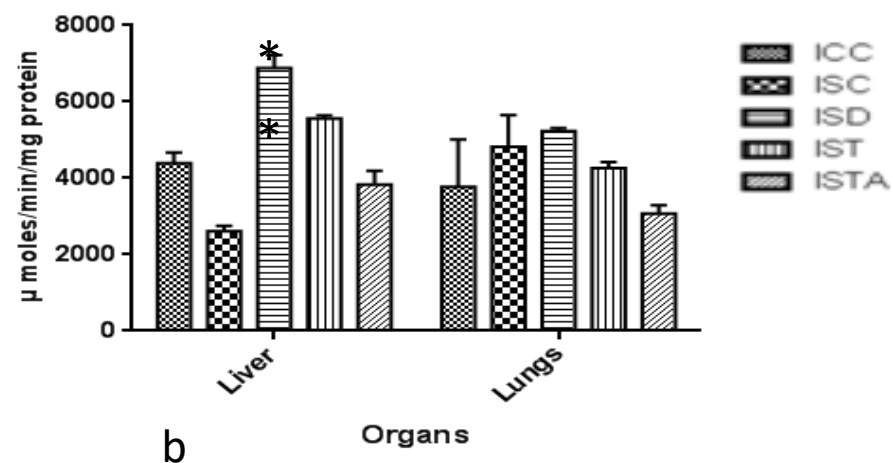

Figure 8 Levels of biochemical enzymes: (a) Superoxide dismutase; (b) Catalase and (c) Malondialdehyde in the liver and lungs of Immunocompetent control (ICC), Immunosuppressed control (ISC), Immunosuppressed disease induced (ISD), Immunosuppressed treated (IST) and Immunosuppressed treated with amphotericin B. (ISTA).Values are Mean \pm SEM, $(\mathrm{n}=5) ; * \mathrm{P}<0.05, * * \mathrm{P}<0.01$ and $\# * \mathrm{P}<0.0001$ (Statistically significant compared with normal control, ICC: using GraphPad style). 


\section{DISCUSSION}

In the effort to conquer the increasing threat of infectious fungi to humans, natural products from microbial sources appear to be the most favorable alternatives to current antifungals. In this context a number of antifungal peptides have been isolated from bacteria for example bacitracin, iturins, polymyxin, subtilisin and fengycin that have potent antifungal activity.

Studies focused on deciphering the mechanism of action of bacitracin sugges that it inhibits the formation of the bacterial cell wall (Stone and Strominger, 1971). In the present study, both the flow cytometric and confocal microscopic analyses exhibit the cidal nature of bacitracin against $C$. $n$. grubii. However, the minimum fungicidal concentration of bacitracin was found to be $5.5 \mathrm{mg} / \mathrm{ml}$ which indeed is very high. But even at higher concentrations $(15 \mathrm{mg} / \mathrm{kg}$ bw/day $)$ bacitracin was found to be well tolerated and caused no harm to the animals.

Neutrophils and lymphocytes are integral components of the innate immunity, and their levels can indicate the presence of any pathological condition in the body (Celkan and Sirin Koc, 2015). In case of the disease induced group decrease in the neutrophil levels and increase in the level of lymphocytes was observed. However after treatment the level of the neutrophils and lymphocytes became in consistence with the control group suggesting recovery due to treatment.

Reactive oxygen species (ROS) exercises a broad range of biological impacts ranging from physiological regulatory functions to harmful changes involved in the pathogenesis of growing numbers of illnesses (Alfadda and Sallam, 2012) In this study the levels of the enzymatic markers of oxidative stress like SOD, Catalase and MDA were evaluated to ascertain the role of bacitracin as a therapeutic. The level of superoxide dismutase was found to be lowered in the diseased condition which was increased after the treatment with bacitracin Probably chronic cryptococcal infection leads to mitochondrial damage which disables the production of SOD resulting in low SOD value in disease induced condition (Traykova, 2013).

Catalase plays a pivotal role in the conversion of harmful hydrogen peroxide (produced due to the ROS) into non-harmful water and oxygen (Sies, 1997). The catalase levels were found to be higher in the disease induced group and lowered down to the levels of control after treatment with bacitracin depicting improvement in the diseased condition.

Apart from being recognized as an end product of the lipid peroxidation, Malondialdehyde (MDA) is also considered to be a biomarker for oxidative stress (Grotto et al. 2009). The results obtained in this study are in unanimity with the humongous scientific literature available which suggests that diseased condition causes an increase in the MDA levels (Grotto et al. 2009). But after treatment with bacitracin a lowering of the MDA levels was evident exhibiting a reduction in the lipid peroxidation.

An antifungal entity obtained from Bacillus licheniformis, the same organism from which bacitracin is obtained, was found to be effective against Curvularia spp., Alternaria spp., Aspergillus spp. (e.g., A. flavus, A. niger), Diplodia maydis, Penicillium spp., Fusarium spp. (including F. moniliforme, F. oxysporum, $F$. roseum), Helminthosporeum spp. (including $H$. maydis), Magnaporthepoae, Rhizopus spp. and Rhizoctonia solani (Neyra and Sadasivan, 1997).

Polymyxin B, a surface active bactericidal antibiotic, showed activity at relatively low concentrations against $S$. cerevisiae and $C$. albicans (Schwartz et al. 1972). Polymyxin was found to be more effective for $S$. cerevisiae than $C$. albicans. Newton and co-workers (1956) reported that a difference in the composition of the membrane phospholipid creates a difference in the antibacterial activity of polymyxin (Newton, 1956). However, there are also reports where contrasting results were achieved for instance 45 clinical isolates of $C$. albicans were found to be non-susceptible to the activity of polymyxin and 12 isolates of $C$. tropicalis were found to be susceptible for the drug (Hsu et al. 2017). Polymyxin also showed variable activity against the capsular and acapsular strains of $C$. neoformans (Zhai and Lin, 2012). However, in our case bacitracin, which is also a product of Bacillus species (Bacillus licheniformis), exhibited a high MIC value $(5.5 \mathrm{mg} / \mathrm{ml})$ against $C . n$. grubii.

Source organism, target fungal pathogens and MIC range of some antifungals peptides of bacterial origin have been summarized in table 3 .

Table 3 Antifungal activity of peptides obtained from bacteria

\begin{tabular}{|c|c|c|c|c|}
\hline Peptide & Origin & Target organism & MIC range & Reference \\
\hline $\mathrm{AF} 3, \mathrm{AF} 4, \mathrm{AF} 5$ & Bacillus subtilis (RLID 12.1) & 64 Candidal and 17 Cryptococcal isolates & $2.83-3.31 \mu \mathrm{g} / \mathrm{ml}$ & Ramachandran et al. 2018 \\
\hline $\begin{array}{l}\text { Bacillomycin } \mathrm{D} \\
\text { (analog } 1 \text { and analog } \\
\text { 2) }\end{array}$ & Bacillus subtilis AU195 & Fusarium oxysporum & $\begin{array}{l}6 \mu \mathrm{g} \text { for both } \\
\text { analogs }\end{array}$ & Moyne et al. 2001 \\
\hline Fengycin & Bacillus subtilis F-29-3 & Fusarium sp. & $10 \mu \mathrm{g} / \mathrm{ml}$ & Vanittanakom et al. 1986 \\
\hline \multirow[t]{7}{*}{ Bacillomycin } & \multirow[t]{7}{*}{ Bacillus subtilis } & Microsporum sp. & $0.010 \mathrm{mg} / \mathrm{ml}$ & \multirow{7}{*}{ Landy et al. 1948} \\
\hline & & Trichophyton sp. & $0.010 \mathrm{mg} / \mathrm{ml}$ & \\
\hline & & C. albicans & $0.010 \mathrm{mg} / \mathrm{ml}$ & \\
\hline & & Blastomyces dermatitidis(Mycelial) & $0.0025 \mathrm{mg} / \mathrm{ml}$ & \\
\hline & & Blastomyces dermatitidis (Yeast) & $0.001 \mathrm{mg} / \mathrm{ml}$ & \\
\hline & & Coccidiodes immitis & $0.005 \mathrm{mg} / \mathrm{ml}$ & \\
\hline & & Histoplasma capsulatum & $0.005 \mathrm{mg} / \mathrm{ml}$ & \\
\hline \multirow[t]{8}{*}{ Bacillomycin F } & \multirow[t]{8}{*}{ Bacillus subtilis strain 1164} & Aspergillus niger & $40 \mu \mathrm{g} / \mathrm{ml}$ & \multirow[t]{8}{*}{ Mhammedi et al. 1982} \\
\hline & & Neurospora crassa & $80 \mu \mathrm{g} / \mathrm{ml}$ & \\
\hline & & Penicillium chrysogenum & $20 \mu \mathrm{g} / \mathrm{ml}$ & \\
\hline & & Rhodotorula pilimanae & $80 \mu \mathrm{g} / \mathrm{ml}$ & \\
\hline & & Trichophyton mentagrophytes & $20 \mu \mathrm{g} / \mathrm{ml}$ & \\
\hline & & C.albicans & $40 \mu \mathrm{g} / \mathrm{ml}$ & \\
\hline & & C.tropicalis & $40 \mu \mathrm{g} / \mathrm{ml}$ & \\
\hline & & Saccharomyces cerevisiae & $10 \mu \mathrm{g} / \mathrm{ml}$ & \\
\hline \multirow[t]{6}{*}{ Lipopetides } & \multirow[t]{6}{*}{ Bacillus amyloliquefaciens } & F. oxysporum & $250-750 \mu \mathrm{g} / \mathrm{ml}$ & \multirow[t]{6}{*}{ Singh et al. 2014} \\
\hline & & Cladosporium cladosporioides & $750-2000 \mu \mathrm{g} / \mathrm{ml}$ & \\
\hline & & Scopulariopsis Acremonium & $125-500 \mu \mathrm{g} / \mathrm{ml}$ & \\
\hline & & Trichophyton rubrum & $750-2000 \mu \mathrm{g} / \mathrm{ml}$ & \\
\hline & & Microsporum gypseum & $125-500 \mu \mathrm{g} / \mathrm{ml}$ & \\
\hline & & A. alternate & $500-2000 \mu \mathrm{g} / \mathrm{ml}$ & \\
\hline
\end{tabular}

\begin{tabular}{llll}
\hline Iturin & B. pumilus HY1 & A. flavus & $52 \mu \mathrm{g} / \mathrm{ml}$ \\
\hline
\end{tabular}

\section{CONCLUSION}

In this study, bacitracin, a group of cyclic peptides produced by $B$. licheniformi was tested for its antifungal activity. It was found to have moderate anticryptococcal activity. Although, its in-vivo treatment was not found effective but the structural diversity it possesses will be helpful in the synthesis of its derivatives and design of its mimetics.
Acknowledgement: The authors would like to thank Principal, Mahila Mahavidyalaya for providing the infrastructure facilities. The authors also wish to thank DST-SERB, New Delhi for providing grant (EMR/2016/001396). One of the authors, Neelabh would like to thank Indian Council of Medical Research (ICMR) for providing Senior Research Fellowship. However, this fellowship was not used in any way to fund this work. The authors are also thankful to Dr. 
Radha Chaube and Sandhya Sharma for photomicrography, Dr. Biplob Koch and Mr. Nishant Kumar Rana for flow cytometry studies.

\section{REFERENCES}

Clements, J. J., \& Peacock, J. J. (1990). Amphotericin B revisited: reassessment of toxicity. The American journal of medicine, $88(5 \mathrm{~N}), 22 \mathrm{~N}-27 \mathrm{~N}$.doi na

Enoch, D. A., Ludlam, H. A., \& Brown, N. M. (2006). Invasive fungal infections: a review of epidemiology and management options. Journal of medical microbiology, 55(7), 809-818. http://dx.doi.org//10.1099/jmm.0.46548-0

Saravolatz, L. D., Johnson, L. B., \& Kauffman, C. A. (2003). Voriconazole: a new triazole antifungal agent. Clinical infectious diseases, 36(5), 630-637. https://doi.org/10.1086/367933

Roemer, T., \& Krysan, D. J. (2014). Antifungal drug development: challenges, unmet clinical needs, and new approaches. Cold Spring Harbor perspectives in medicine, 4(5), a019703. https://doi.org/10.1101/cshperspect.a019703

Weidman, F. D. (1927). Laboratory aspects of epidermophytosis. Archives of Dermatology and Syphilology, 15(4), 415-450. https://doi.org/10.1001/archderm.1927.02370280031002

Waksman, S. A. (1941). Antagonistic relations of microörganisms. Bacteriological reviews, 5(3), 231. doi na

Johnson, B. A., Anker, H., \& Meleney, F. L. (1945). Bacitracin: a new antibiotic produced by a member of the B. subtilis group. Science, 102(2650), 376-377. https://doi.org/10.1126/science.102.2650.376

Meleney, F. L., \& Johnson, B. A. (1949). Bacitracin. The American journal of medicine, 7(6), 794-806. https://doi.org/10.1016/0002-9343(49)90418-0

Mescher, M. F., Strominger, J. L., \& Watson, S. W. (1974). Protein and carbohydrate composition of the cell envelope of Halobacterium salinarium. Journal of Bacteriology, 120(2), 945-954. doi na

Chitarra, G. S., Breeuwer, P., Nout, M. J. R., Van Aelst, A. C., Rombouts, F. M \& Abee, T. (2003). An antifungal compound produced by Bacillus subtilis YM 10-20 inhibits germination of Penicillium roqueforti conidiospores. Journal of Applied Microbiology, 94(2), 159-166. https://doi.org/10.1046/j.13652672.2003.01819.x

Dickerhof, N., Kleffmann, T., Jack, R., \& McCormick, S. (2011). Bacitracin inhibits the reductive activity of protein disulfide isomerase by disulfide bond formation with free cysteines in the substrate-binding domain. The FEBS journal, 278(12), 2034-2043. https://doi.org/10.1111/j.1742-4658.2011.08119.x

Wilkinson, B., \& Gilbert, H. F. (2004). Protein disulfide isomerase. Biochimica et Biophysica Acta (BBA)-Proteins and Proteomics, 1699(1-2), 35-44. https://doi.org/10.1016/j.bbapap.2004.02.017

Freedman, R. B., Klappa, P., \& Ruddock, L. W. (2002). Protein disulfide isomerases exploit synergy between catalytic and specific binding domains. EMBO reports, 3(2), 136-140. https://doi.org/10.1093/emboreports/kvf035

Serve, O., Kamiya, Y., \& Kato, K. (2012). Redox-dependent chaperoning, following PDI footsteps. Proteomics Research Journal, 3(1/2), 69. doi na

Wang, S., Park, S., Kodali, V. K., Han, J., Yip, T., Chen, Z., \& Kaufman, R. J. (2015). Identification of protein disulfide isomerase 1 as a key isomerase for disulfide bond formation in apolipoprotein B100. Molecular biology of the cell, 26(4), 594-604. https://doi.org/10.1091/mbc.E14-08-1274

Perfect, J. R. (2006). Cryptococcus neoformans: the yeast that likes it hot. FEMS yeast research, 6(4), 463-468. https://doi.org/10.1111/j.1567-1364.2006.00051.x Clinical and Laboratory Standards Institute (CLSI), Reference Method for Broth Dilution Antifungal Susceptibility Testing of Yeasts, Approved Standard, 2nd ed., NCCLS document M27-A3, 2008. doi na

Martinez, S. C., Tanabe, K., Cras-Méneur, C., Abumrad, N. A., Bernal-Mizrachi, E., \& Permutt, M. A. (2008). Inhibition of Foxo1 protects pancreatic islet $\beta$-cells against fatty acid and endoplasmic reticulum stress-induced apoptosis. Diabetes, 57(4), 846-859. https://doi.org/10.2337/db07-0595

Green, L., Petersen, B., Steimel, L., Haeber, P., \& Current, W. (1994). Rapid determination of antifungal activity by flow cytometry. Journal of Clinical Microbiology, 32(4), 1088-1091. doi na

Singh, K., Rani, J., Rai, G. K., \& Singh, M. (2017). The Southeastern Asian house mouse (Mus musculus castaneus Linn.) as a new passenger host for Cryptococcus neoformans var. grubii molecular type VNI. Medical mycology, 55(8), 820-827. https://doi.org/10.1093/mmy/myx001

Zaragoza, O., Alvarez, M., Telzak, A., Rivera, J., \& Casadevall, A. (2007). The relative susceptibility of mouse strains to pulmonary Cryptococcus neoformans infection is associated with pleiotropic differences in the immune response. Infection and immunity, 75(6), 2729-2739. https://doi.org/10.1128/IAI.00094-07

Lowry, O. H., Rosebrough, N. J., Farr, A. L., \& Randall, R. J. (1951). Protein measurement with the Folin phenol reagent. Journal of biological chemistry, 193 265-275. doi na

Ohkawa, H., Ohishi, N., \& Yagi, K. (1979). Assay for lipid peroxides in animal tissues by thiobarbituric acid reaction. Analytical biochemistry, 95(2), 351-358. https://doi.org/10.1016/0003-2697(79)90738-3

Aebi, H. (1974). Catalase. In Methods of enzymatic analysis (pp. 673-684) Academic press. https://doi.org/10.1016/B978-0-12-091302-2.50032-3
Das, K., Samanta, L., \& Chainy, G. B. N. (2000). A modified spectrophotometric assay of superoxide dismutase using nitrite formation by superoxide radicals. Indian Journal of Biochemistry and Biophysics 37(3), 201-204. http://nopr.niscair.res.in/handle/123456789/15379

Stone, K. J., \& Strominger, J. L. (1971). Mechanism of action of bacitracin: complexation with metal ion and C55-isoprenyl pyrophosphate. Proceedings of the National Academy of Sciences, 68(12), 3223-3227. https://doi.org/10.1073/pnas.68.12.3223

Celkan, T., \& Koç, B. Ş. (2015). Approach to the patient with neutropenia in childhood. Turkish Archives of Pediatrics/Türk Pediatri Arşivi, 50(3), 136 https://doi.org/10.5152/TurkPediatriArs.2015.2295

Alfadda, A. A., \& Sallam, R. M. (2012). Reactive oxygen species in health and disease. BioMed Research

International, 2012 https://doi.org/10.1155/2012/936486

Traykova, Does Oxidative stress causes decrease or increase in SOD activity? 2013 Available

at:https://www.researchgate.net/post/Does Oxidative stress causes decrease or increase_in_SOD_activity. Accessed on June 7, 2019. doi na

Sies, H (1997). Physiological society symposium: Impaired endothelial and smooth muscle cell function in oxidative stress. Experimental Physiology, 82(2), 291-5. doi na

Grotto, D., Maria, L. S., Valentini, J., Paniz, C., Schmitt, G., Garcia, S. C., et al (2009). Importance of the lipid peroxidation biomarkers and methodologica aspects for malondialdehyde quantification. Quimica Nova, 32(1), 169-174 http://dx.doi.org/10.1590/S0100-40422009000100032

Neyra, CA, Sadasivan, L U.S. Patent No. 5,665,354, Washington, DC: U.S Patent and Trademark Office, 1997. doi na

Schwartz, S. N., Medoff, G., Kobayashi, G. S., Kwan, C. N., \& Schlessinger, D. (1972). Antifungal properties of polymyxin B and its potentiation of tetracycline as an antifungal agent. Antimicrobial agents and chemotherapy, 2(1), 36-40. http://dx.doi.org/10.1128/AAC.2.1.36

Newton, B. A. (1956). The properties and mode of action of the polymyxins. Bacteriological reviews, 20(1), 14. doi na

Hsu, L. H., Wang, H. F., Sun, P. L., Hu, F. R., \& Chen, Y. L. (2017). The antibiotic polymyxin B exhibits novel antifungal activity against Fusarium species. International journal of antimicrobial agents, 49(6), 740-748. https://doi.org/10.1016/j.ijantimicag.2017.01.029

Zhai, B., \& Lin, X. (2013). Evaluation of the anticryptococcal activity of the antibiotic polymyxin $\mathrm{B}$ in vitro and in vivo. International journal of antimicrobial agents, 41(3), https://doi.org/10.1016/j.ijantimicag.2012.11.006

Ramachandran, R., Shrivastava, M., Narayanan, N. N., Thakur, R. L., Chakrabarti, A., \& Roy, U. (2018). Evaluation of antifungal efficacy of three new cyclic lipopeptides of the class bacillomycin from Bacillus subtilis RLID 12.1. Antimicrobial agents and chemotherapy,62(1), e01457-17. https://doi.org/10.1128/AAC.01457-17

Moyne, A. L., Shelby, R., Cleveland, T. E., \& Tuzun, S. (2001). Bacillomycin D: an iturin with antifungal activity against Aspergillus flavus. Journal of applied microbiology, 90(4), 622-629. https://doi.org/10.1046/j.1365-2672.2001.01290.x Vanittanakom, N., Loeffler, W., Koch, U., \& Jung, G. (1986). Fengycin-a novel antifungal lipopeptide antibiotic produced by Bacillus subtilis F-29-3. The Journal of antibiotics, 39(7), 888-901. https://doi.org/10.7164/antibiotics.39.888 Landy, M. W. G. H., Warren, G. H., RosenmanM, S. B., \& Colio, L. G. (1948) Bacillomycin: an antibiotic from Bacillus subtilis active against pathogenic fungi. Proceedings of the Society for Experimental Biology and Medicine, 67(4), 539-541. https://doi.org/10.3181/00379727-67-16367

Mhammedi, A., Peypoux, F., Besson, F., \& Michel, G. (1982). Bacillomycin F, a new antibiotic of iturin group: isolation and characterization. The Journal of antibiotics, 35(3), 306-311. https://doi.org/10.7164/antibiotics.35.306

Singh, A. K., Rautela, R., \& Cameotra, S. S. (2014). Substrate dependent in vitro antifungal activity of Bacillus sp strain AR2. Microbial cell factories, 13(1), 67 https://doi.org/10.1186/1475-2859-13-67

Cho, K. M., Math, R. K., Hong, S. Y., Islam, S. M. A., Mandanna, D. K., Cho, J. J., .. \& Yun, H. D. (2009). Iturin produced by Bacillus pumilus HY1 from Korean soybean sauce (kanjang) inhibits growth of aflatoxin producing fungi. Food Control, 20(4), https://doi.org/10.1016/i.foodcont.2008.07.010 